Food, Dairy and Home Economic Research

http:/www.journals.zu.edu.eg/journalDisplay.aspx?Journalld=1\&queryType=Master

\title{
EFFECT OF MILK TYPE ON CAERPHILLY LIKE CHEESE QUALITY
}

\author{
Mohamed Sh. Gomaa*, M.E. Abdel-Aziz, M.M.M. Refaey and M. Abd EIfattah \\ Dairy Dept., Fac. Agric., Mansoura Univ., Egypt
}

Received: 08/02/2020 ; Accepted: 15/03/2020

\begin{abstract}
Caerphilly cheese is a British Welsh cheese originally processed from cow's milk and similar in its characteristics with Ras cheese, the most popular hard cheese variety in Egypt, which needs three to six monthes to sharp flavour. However Caerphilly cheese this period can be shorter than 3 weeks to reach the same organoleptic properties of Ras cheese. To process that variety under the Egyptian conditions, three types of milk processed into Caerphilly cheese as the following, $100 \%$ cow's milk, 100\% buffalo's milk and mixture(cows: buffalos' 1:1). Resultant cheeses were chemically, physically, microbiologically and sensory evaluated at zero time and throughout the repining period. Results indicated that, cow's milk gained higher quality cheese with low yield (12.91\%) while, buffalo's milk gave harder and harsh cheese with higher yield $(15.80 \%)$, as well as, mixture milk gained medium yield (13.01\%) and the highest score of sensory properties $(78 / 100)$ in fresh cheese and (88/100) after the 45days of storage period compared with other treatments. Cheese made from buffalo's milk obtained the highest value for each of total solids, fat, ash and total protein when compared with other treatments either in fresh or after 15 days of ripening period. Cheese made from mixture milk had the lowest total counts of all types of cheese microfloura either it was fresh or after 15 days of storage. Moreover, mixture milk cheese had the best rheological properties [Adhesiveness $(\mathrm{g})$, Hardiness $(\mathrm{N})$, Springiness $(\mathrm{mm})$, Cohesiveness (Ratio), Gumminess $(\mathrm{N})$, Chewiness (J) and Modulus $(\mathrm{g} / \mathrm{mm})$ ] among cheese treatments. So, from these results it could be recommended to process Caerphilly cheese from mixture from cows and buffalo's milk to obtain the best characteristics and medium yield.
\end{abstract}

Key words: Caerphilly, cheese, cow's, buffalo's, mixture, ripening, physical properties.

\section{INTRODUCTION}

There are over 700 named British cheeses produced in the UK. The regions of England have their own specialty cheeses, made by locals, with milk from local animals, reared on local pastures. The addition of famous herbs, honey and other locally-sourced goodies helps to define regional cheeses. According to the council regulation (EU) no 1151/2012 on protected geographical indications and protected designations of origin, Traditional Welsh Caerphilly/raditional Welsh Caerffili,, EC NO: PDO() PGI(x) Caerphilly, named after the Welsh town where it originated. Caerphilly originally produced in the South Wales town of the same name, Caerphilly (fat/TS content range between $45 \%$ and $55 \%$ ). It has a mild, salty, buttermilk flavour, a crumbly texture and a pale creamy yellow colour. It is, roughly, halfway between a fresh cheese, like ricotta, and an aged cheese, like Cheddar. The universal process method of Caerphilly is curdling cow's milk (pasteurized or unpasteurized) with rennet, then cut, drained and placed in a flat cylindrical mold for a very light pressing. Caerphilly has a recipe similar to those for other crumbly cheeses Cheshire and young Lancashire. Being close to the great mining towns of South Wales the young cheese was a firm favorite amongst mining communities as its shallow height and tough coat made it easy to eat with dirty hands down the mines, whilst its salty, moist curd helped to replace the minerals lost during the hours spent laboring under ground. Its more mature variant (often kept for up to a year)

\footnotetext{
*Corresponding author: Tel. : +201110889183

E-mail address: mahmoud_refae_2004@mans.edu.eg
} 
formed its own tough coat and gradually became harder in texture and stronger in taste with age. There are few traditionally shaped Caerphilly cheeses made today, and only one producer in South Welles. Most Caerphilly is made by the specialist crumbly cheese makers in Lancashire, Cheshire, generally in block form but sometimes in shallow wheels for supermarket pre-packs. This cheese tends to be young, fresh and clean tasting with a pleasant tang. The formed wheel (which is 10 in. diameter $\times 3$ in. thick and weighs 7-9 lb) is then immersed in a brine bath for a day to facilitate the formation of a preservative rind, which is whitened by a dusting with rice flour. The cheese is aged for only about 10 days, in contrast to Cheddars, which are often aged for a year (Stephan and Stephan, 2000).

The cheese is typically made in a wheel, the rind is thin with a brushed mold coat. The interior texture is fairly close with a few mechanical openings (not due to gas) and cakelike due to the acidity. The body is semi-firm. The flavour is slightly acid and fresh when young ( 2 weeks- 2 months); when more mature (3-4 months) the flavour is mild and smooth.

Ras cheese, the only hard Egyptian cheese needs more than 6 monthes to be well ripened and consumed. Possibly to be consumed after three months as pre-matured cheese (Awad et al., 2003).

Ripening cost is very high for Ras cheese, as well as can reach to a nearly flavour for Ras cheese in Caerphilly cheese as shorter time with lowering these costs. The advantage of quickly ripening of Caerphilly like cheese will attract cheese processors to produce that variety of cheese. So, this work was aimed to produce Caerphilly- like cheese under the Egyptian condition from cow's and buffalo's milks and its mixture to present hard type cheese with the same common taste in Ras cheese (Awad et al., 2003).

\section{MATERIALS AND METHODS}

Fresh moring cow's and buffalo's milk were purchased from Faculty of Agriculture Mansoura University Dairy Unit., Local commercial animal liquid rennet was obtained from local market (40 mg/100 kg milk).
Traditional yoghurt starter contained Streptococcus thermophiles and Lactobacillus delberuckii supbs bulgaricus was purchased from Ch. Hansen, Denmark. Commercial food grad salt (El-Nasr saline's, Egypt) was obtained from the local market. Food grade calcium chloride was obtained from El-Gomhouria Company.

\section{Caerphilly Cheese Manufacture}

Caerphilly cheese was made according to Davide (1994) with some modifications in the type of milk (cow's milk, buffalo's milk and their mixture Fig. 1).

Samples of fresh milk and whey were analyzed for TS, Fat, TN, lactose ash, acidity and $\mathrm{pH}$ values. Samples of the examined cheese were tested at intervals periods (fresh, 7, 14, and 45days, and subjected to chemical ,physical and microbiological analysis. Sensory evaluation was also carried out. Yield of the different cheese treatments was calculated when fresh and after 14 days of cheese making.

Moisture content of cheese treatments, $\mathrm{pH}$ values, and the fat content were determined using methods described in AOAC (2000). Acidity, the total nitrogen and the ash content of investigated cheese were estimated according to the method described by Ling (1963). Salt content was estimated according to Kosikowski (1970).

Samples were analyzed at zero time and after 14 days of storage for Total lactic acid bacteria, moulds and yeasts count, according to Standard Methods for the Examination of Dairy Products (1978).

Textural properties were determined according to Szczesniak et al. (1963) by using texture analyzer Lab pro (FTC TMS-pro, USA).

Samples from fresh and stored Caerphilly cheese were organoleptically evaluated according to the scheme described by Nelson and Trout (1956). Cheese yield was calculated by Metzger et al. (2000) formula as follows:

Adjusted yield $=($ actual yield $\times(100-$ actual moisture + actual salt $)) /(100-(55+1.5)$. 


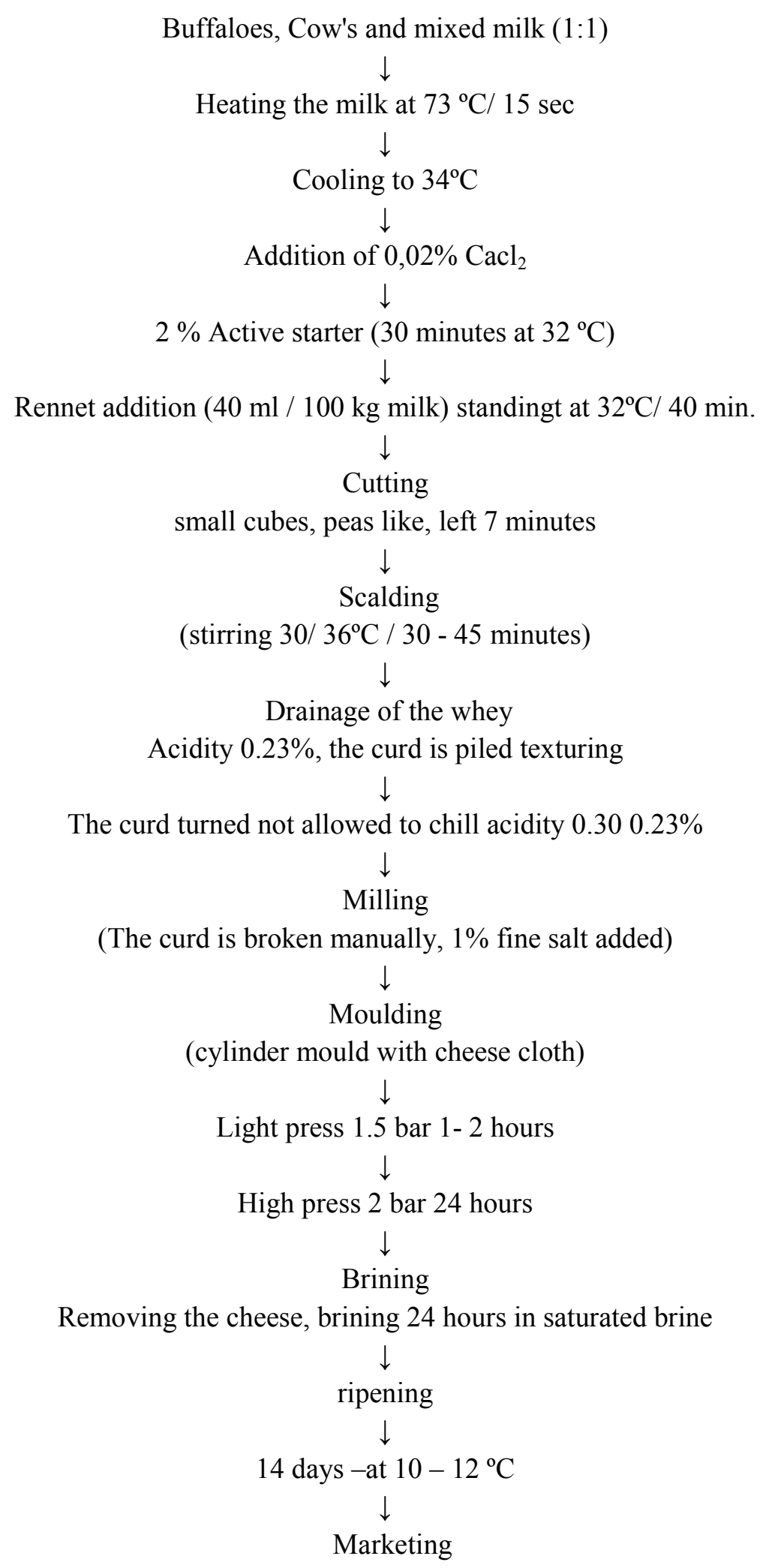

Fig. 1. Caerphilly-like Cheese processing flow chart 


\section{RESULTS AND DISCUSSION}

Illustrated data in Table 1 show the chemical composition of the milk used for cheese making. Casein/Fat ratio was $0.453,0.879$ and 0.483 for buffalo's, cow's and mixed milk, respectively. The total protein content of standardized buffalo milk was higher $(3.8 \%)$ than the mixture milk $(3.2 \%)$. These results are in harmony with obtained results by Abo-EI Naga (1984).

\section{Acidity and pH of Resultant Cheese}

Results of the $\mathrm{pH}$ values of the three cheese treatments decreased throughout the storage period (14 days). The acidity per cent was in an opposite relation with the determined $\mathrm{pH}$ values (5.6/5.2, 5.1/4.9 and 5.2/5.1) for, B,C and $\mathrm{B}+\mathrm{C}$ mixtures of milk treatments, respectively . These results might be due to the increase in the microbial counts of the resultant cheese, and these differences might not be a result of the differences of the types or composition of milk used for making cheese treatment.

\section{Total Solids (TS\%)}

All treatment showed an increase of the total solids per cent after 14 days of storage due to the loss of some cheese moisture by the evaporation process on the refrigerated condition. Moreover, cheese made by buffalo milk gained the heights total solids (48.28/ $49.45 \%)$ per cent compared with the other treatment either in fresh or after 14 days of storage. This is might be due to the native composition of used milk and its high protein content.

\section{Fat and Fat/TS}

Fresh cheese Fat content ranged among $22.38,18.82$ and $20.18 \%$, with the highest content in the buffalo's cheese, while the lowest was in the cow's cheese, and this might be refers to the differences of the milk used in cheese making. In addition, the fat content markedly increased after 14 days and this might be as a result to the rise in the cheese total solids. There were slight differences in Fat/Ts values through the storage period, as they were $(48.28 / 49.45)$, (43.38/44.92 and (46.34/46.84\%) for B, C and B $+\mathrm{C}$ mixture milk treatments, respectively combatable results obtained by Stephan at el. (2000).

\section{Total Protein (TP) and (TP)/(TS) Per cent}

After 14 days of storage total protein were increased in all treatments, owing to the increase in total solids of resultant cheese. TP/TS of the fresh and 14 days ripened cheese were (39.72/ $39.88 \%),(32.32 / 34.01 \%)$ and $(35.51 / 35.51 \%)$ for $\mathrm{B}, \mathrm{C}$ and $\mathrm{B}+\mathrm{C}$ mixture milk treatments respectively. This came in agreement with Michele et al. (2019).

\section{Total Protein and Soluble Nitrogen}

For all cheese treatments soluble nitrogen increased after 14 days of storage since the starter contained a high number of mesophilic bacteria, as it is obvious from the results mentioned in Table 2. It is clear that the buffalo's milk cheese have the highest SN content as a relation to the increase of the cheese microflora, compared with the other cheese treatments. As an indicator for ripping index $\mathrm{SN} / \mathrm{TP}$ was evaluated .Values of SN/TP were $(4.35 / 6.25), 10.91 / 12.50)$ and $(6.86 / 8.56 \%)$ for fresh and after 14 days for $\mathrm{B}, \mathrm{C}$ and $\mathrm{B}+\mathrm{C}$ mixture milk, respectively. So, the using of cow's milk is recommended when the target is the higher ripening those. These results are in agreement with that reported by El-Tahra $\boldsymbol{e t} \boldsymbol{e l}$. (2014).

\section{Salt and Ash Content}

Results Illustrated in Table 2 show that there were slight differences of the salt content followed by ash content among all cheese treatments at the beginning of storage period, and the buffalo's milk cheese had the highest content. Also, these results reveal that there were a progress in the salt content throughout the storage, and that might be as a result to the rise in all stored cheese treatments total solids. These results agree with Michele et al. (2019).

\section{Effect of Milk Type on Caerphilly Cheese Yield}

Table 3 deals with the yield of Caerphilly cheese in a correlation with the type of milk used in the processing. The yield of the three treatments are calculated after 6 hours of lifting the cylinder cheese from brined solution, and the yield was estimated after 14 days of storage at $12 \pm 2^{\circ} \mathrm{C}$. As it is expected the highest yield was 
Zagazig J. Agric. Res., Vol. 47 No. (2) 2020

Table 1. Gross chemical composition of different milks

\begin{tabular}{lcccccc}
\hline Type of milk & Fat (\%) & TS & F/TS (\%) & Protein (\%) & Protein /Fat ratio & Ash(\%) \\
\hline Buffalo,s milk (B) & 6.8 & 16.5 & 41.2 & 3.8 & 0.453 & 1.1 \\
Cow's milk (C) & 3.4 & 11.7 & 30.7 & 2.9 & 0.879 & 0.92 \\
B + C (1: 1) & 5.3 & 14.1 & 37.6 & 3.2 & 0483 & 0.98 \\
\hline
\end{tabular}

Table 2. Effect of milk type on the gross chemical composition of Caerphilly type Cheese

\begin{tabular}{|c|c|c|c|c|c|c|c|c|c|c|c|c|}
\hline $\begin{array}{c}\text { Type of } \\
\text { milk }\end{array}$ & $\begin{array}{c}\text { Storage } \\
\text { period }\end{array}$ & pH & $\begin{array}{l}\text { TS } \\
(\%)\end{array}$ & $\begin{array}{l}\text { Fat } \\
(\%)\end{array}$ & $\begin{array}{c}\text { F/TS } \\
(\%)\end{array}$ & $\begin{array}{l}\text { TP } \\
\%)\end{array}$ & $\begin{array}{c}\text { TP/TS } \\
(\%)\end{array}$ & $\begin{array}{l}\text { SN } \\
(\%)\end{array}$ & $\begin{array}{c}\text { SN/TS } \\
(\%)\end{array}$ & $\begin{array}{l}\text { Salt } \\
(\%)\end{array}$ & $\begin{array}{c}\text { Salt/TS } \\
(\%)\end{array}$ & $\begin{array}{l}\text { Ash } \\
\text { (\%) }\end{array}$ \\
\hline \multirow[t]{2}{*}{$\overline{\text { Buffalo }}$} & Fresh & 5.6 & 48.28 & 22.38 & 48.28 & 18.41 & 39.72 & 0.80 & 4.35 & 2.16 & 4.66 & 5.08 \\
\hline & 14 days & 5.2 & 48.45 & 24.81 & 49.45 & 20.01 & 39.88 & 1.25 & 6.25 & 3.61 & 7.20 & 5.94 \\
\hline \multirow{2}{*}{ Cow } & Fresh & 5.1 & 43.38 & 18.82 & 43.38 & 14.02 & 32.32 & 1.53 & 10.91 & 1.94 & 4.48 & 4.16 \\
\hline & 14 days & 4.9 & 44.92 & 20.91 & 44.92 & 15.83 & 34.01 & 1.98 & 12.50 & 2.43 & 5.22 & 5.02 \\
\hline \multirow{2}{*}{$B+C(1: 1)$} & Fresh & 5.2 & 46.34 & 20.18 & 46.34 & 15.64 & 35.51 & 1.06 & 6.86 & 2.01 & 3.52 & 4.89 \\
\hline & 14 days & 5.1 & 46.84 & 30.22 & 46.84 & 16.93 & 35.51 & 1.45 & 8.56 & 3.52 & 4.62 & 5.39 \\
\hline
\end{tabular}

Table 3. Effect of milk type on yield of Caerphilly cheese during storage period

\begin{tabular}{lccc}
\hline Treatment & B & C & B + C (1:1) \\
\hline Yield of fresh cheese & 16.52 & 13.86 & 14.81 \\
Yield of ripened cheese (14 days) & 13.95 & 10.55 & 11.93 \\
Losses of weight & 2.57 & 3.31 & 2.88 \\
\hline
\end{tabular}

detected in the buffalos milk cheese since it has the highest total solids, casein and fat. The lowest of $3.31 \%$ was detected in cow's milk cheese, mixing buffalos milk with cow's milk raised the yield to $14.81 \%$. After 14 days of ripening at storage conditions the yield decreased for the three types of cheese to reach 13.95, 10.55 and $11.93 \%$ for $\mathrm{B}, \mathrm{C}$ and mixed cheese treatments, respectively. Caerphilly cheese processes from buffalo's or mixture milk were of higher yield and lower losses in yield during storage (El-Metwally, 2013). The addition of buffalo milk to cow's milk decreased losses in weight of cheese.

\section{Effect of Milk Type on the Gross Chemical Composition of Strained Whey}

Table 4 illustrates the gross chemical composition of strained whey. Whey of buffalo's milk TS was higher than that of cow's or mixture milk because TS of buffalo's milk is higher in TS, Fat loses was the highest because of the higher percentage of fat content of buffalo's milk and also for the larger fat globules of buffalo's milk fat than cow's milk fat globules. Acidity values is higher in cow's milk whey since starter was more active in cow's milk than buffalo's milk owing to the higher buffer capacity of buffalo's milk than cow's milk, 
Table 4. Chemical composition of type cheese whey

\begin{tabular}{lcccccccc}
\hline Type of whey & pH & Acidity (\%) & TS (\%) & Fat (\%) & F/TS (\%) & Protein (\%) & P/TS (\%) & Ash (\%) \\
\hline Buffalo's & 5.8 & 0.30 & 6.1 & 1.2 & 19.67 & 1.02 & 16.72 & 0.48 \\
Cow's & 5.5 & 0.39 & 5.3 & 0.44 & 8.00 & 0.68 & 12.63 & 0.33 \\
B + C ( 1:1) & 5.7 & 0.36 & 5.7 & 0.9 & 15.79 & 0.74 & 12.98 & 0.39 \\
\hline
\end{tabular}

mixed milk values were of intermediate value between cow's and buffalo's milk whey. El-Metwally (2013) found that total solids (TS) of buffalo's milk whey treatment has the highest of $6.1 \%$ among all milk treatments, which is due to the higher total solid in buffalo's milk. The lowest TS (5.3\%) was for cow's milk treatment. Values of fat in whey ranged between 0.44 and $1.2 \%$. The highest fat content was for buffalo's milk treatment It is well known that buffalo milk fat globules are of the largest size, On the other hand, the highest fat content of buffalo milk helped the escape of higher percent of fat into the whey. Losses of whey protein ranged between 1.02 and $0.74 \%$. The highest (1.02) was for buffalo milk, which contains the highest protein percentage among other milks. The lowest $(0.68 \%)$ was for cow's milk treatment. Similar results were obtained by El-Zoghby (1994) and Zaky (2014).

\section{Effect of Milk Type on Microbiological Properties}

Results in Table 5 show the total microbial counts on the nutrient agar, Lactic acid bacteria agar, Mac Conkey and potato dextrose Agar (PDA). Heat treatment of milk led to high reduction of total microbial count, the colonies appeared on lactic acid bacteria and nutrient agar representing mainly the number of added mesospheric starter. From the results in the same Table, enumeration of either total count or lactic acid bacteria was higher in cheese of cow's milk, followed by mixed milk and the lowest enumeration was in buffalo's milk cheese. It is well known that starter culture is more active in cow's milk than buffalo's milk since buffalo's milk had higher buffer capacity and higher fat content, which slow the propagation of bacteria. Also, this higher number of lactic acid bacteria is highly responsible for the ripening of Caerphilly type cheese, because the heat treatment inactivates most of indigenous enzymes of milk. Very few colonies were enumerated on Mac Conkey agar being nil. Detected in fresh cheese and disappeared during storage. No found colonies were detected on potato dextrose agar in fresh cheese and few numbers were detected after 14 days which due to the recontamination from the storage room.

Results belonging the Textural Profile in fresh and old cheese are tabulated in Table 6 which shows the calculated rheological parameters of fresh and 45 days Caerphilly -like cheese.

\section{Hardness}

The strength of cheeses which increased for the three cheese after 14 days of storage, always the buffalo's milk cheese had the highest values Since the matrix formed from rigid casein contain higher calcium content and bigger casein micelles. The incuse of Hardness values after 14 days is owing to the increase in total solids. Similar results were obtained by Naema (2017).

\section{Adhesiveness}

It is clear from Table 6 the increase of adhesiveness after 14 days of storage, also the highest values for buffalo's milk cheese, values were (32.98/83.41), (38.62/86.71) and (46.15 and 111.66) for $\mathrm{B}, \mathrm{C}$ and $\mathrm{B}+\mathrm{C}$ treatments, respectively. Similar results were obtained by Zehern and Nusbaum (1992).

\section{Cohesiveness}

Cohesiveness is the measure of foods internal bonds making up the body of the product values. Cohesiveness decreased slightly after 14 days of storage being $(0.47 / 0.43),(0.62 / 0.33)$ and $(0.53$ and 0.46) for $\mathrm{B}, \mathrm{C}$ and $\mathrm{B}+\mathrm{C}$ treatments, respectively which came in harmony with Awad et al. (2005) and Zaky (2014). 
Zagazig J. Agric. Res., Vol. 47 No. (2) 2020

Table 5. Effect of milk type on microbiological properties of Caerphilly Cheese during storage period

\begin{tabular}{|c|c|c|c|c|}
\hline \multirow{2}{*}{$\begin{array}{c}\text { Micobiological } \\
\text { counts }\end{array}$} & \multirow[t]{2}{*}{ Storage Period } & \multicolumn{3}{|c|}{ Treatment } \\
\hline & & Buffalo 100\% & Cow 100\% & Mixed 1:1 \\
\hline Neutrient Agar & Fresh & 20.00 & 30.00 & 16.00 \\
\hline$T, C \times 10^{4} \mathrm{cfu} / \mathrm{g}$ & 14 days & 22.00 & 35.00 & 15.00 \\
\hline \multirow{2}{*}{ L.A.B $\times 10^{4} \mathrm{cfu} / \mathrm{g}$} & Fresh & 17.00 & 26.00 & 11.00 \\
\hline & 14 days & 29.00 & 33.00 & 25.00 \\
\hline \multirow[t]{2}{*}{$M^{*} . Y \times 10^{2} \mathrm{cfu} / \mathrm{g}$} & Fresh & ND & ND & ND \\
\hline & 14 days & 7.00 & $9 . .00$ & 8.00 \\
\hline \multirow{2}{*}{ Ecoli $\times 10^{2} \mathrm{cfu} / \mathrm{g}$} & Fresh & ND & ND & ND \\
\hline & 14 days & ND & ND & ND \\
\hline
\end{tabular}

Table 6. Effect of milk type on textural profile of Caerphilly Cheese during storage period

\begin{tabular}{lcccc}
\hline Parameter & $\begin{array}{c}\text { Storage period } \\
\text { (day) }\end{array}$ & \multicolumn{3}{c}{ Treatment } \\
\cline { 3 - 5 } & & Buffalo 100\% & Cow 100\% & Mixed 1:1 \\
\hline Hardiness (N) & Fresh & 412 & 398 & 434 \\
& $\mathbf{1 4}$ days & 1403 & 1023 & 1099 \\
Adhesiveness (g) & Fresh & 32.98 & 38.62 & 49.15 \\
& $\mathbf{1 4}$ days & 138.41 & 86.71 & 111.66 \\
Springiness (mm) & Fresh & 5.61 & 4.67 & 4.94 \\
Cohesiveness (Ratio) & $\mathbf{1 4}$ days & 5.56 & 4.34 & 4.39 \\
& Fresh & 0.47 & 0.62 & 0.53 \\
Gumminess (N) & $\mathbf{1 4}$ days & 0.43 & 0.33 & 0.46 \\
Chewiness (J) & Fresh & 193.64 & 238.8 & 230 \\
& $\mathbf{1 4}$ days & 605.00 & 638.0 & 505 \\
Modulus (g/mm) & Fresh & 1286.32 & 1115.2 & 1136.26 \\
& $\mathbf{1 4}$ days & 3489.15 & 1157.94 & 2163.22 \\
\hline
\end{tabular}




\section{Springiness}

Springiness or elasticity's is defined as a rate at which a deformed material returns to its original shape on removal of the deforming force. From Table 6, slight increase in value of buffalo's springiness from 5.61 to $5.76 \mathrm{~mm}$, followed by the decrease occurred in cow's and mixed milk cheese after 14 days of storage. These results are in agreement with those obtained by Awed et al. (2005) and Helal (2006).

\section{Chewiness}

Chewiness is the energy required to chew a solid food product to a state where it is ready for swallowing (Szczesniak et al., 1963; Bourne, 1978). Table 6 shows the values of chewiness which markedly increased by the storage time. The highest values were for buffalo's milk fresh and stored cheese (1286.32/ 3489.15), the lowest was for cow's milk cheese (1115.2/ 1157.94) these results agree with Zaky (2014).

\section{Modulus}

Measured in $\mathrm{g} / \mathrm{mm}$ values rise as the storage period increased, the highest values were for buffalo's cheese followed by mixed milk the lowest value was for cow's 'milk cheese (24.15/ 78.78), (23.18/73.29) and (21.27/71.19).

\section{Organoleptic Properties of Careipghily Like Cheese}

The opinions of the ten judges are summarized as shown in Table 7. The evaluating continued up to 45 days because some people like cheese with sharp peppery flavour for the all treatments as the storage period advanced the body and texture gradually improved since protein hydrolysis continued under the addition of enzymes secreted by lactic acid bacteria, cow's milk cheese had higher scoring points because the casein matrix is not firmer and rigid as casein matrix of buffalo's milk cheese. The coarse texture of buffalo's milk cheese was not highly accepted by the 10 judges. It is well known that buffalo's milk did not give accepted hard cheese, the cheese is always very hard and harsh. Mixing 50\% cow's milk with 50\% buffalo's milk highly improved the body and texture of mixture milk Caerphilly cheese, the feeling of little hardness admired most of judges where the body and texture gained higher scoring points even over the evaluation of cow's milk cheese body and texture. Scoring points were donated for flavours, although buffalo's milk cheese had the highest amount of fat protein and ash, the flavour was not pronounced like what detected in cow's milk cheese. Flavour of mixed milk cheese was highly accepted and gained more scoring points, the rich fat flavour was attractive as well the ripening flavour was easily detected, the intensive yellow colour of cow's milk with the marked softness of the body and texture make the judger more happier with the body and texture of hard cheese of mixed milk cheese. At the end of ripning, total scoring points were $81 / 100,82 / 100$ and $88 / 100$ for B,C and mixture milk cheese, respectively. These results are in agreement with Zaky (2014) who found that appearance of all Caerphilly cheese slightly decreased as the storage time advanced, while texture and flavour markedly increased as a result of storage. Flavour of cow's milk gained 29,31 and 33 out of 35 for fresh and stored cheese, while buffalo milk cheese gained 18, 21, 22 and 24 points, respectively. The addition of cow's milk to buffalo milk improved the flavour $32,33,35$ and 37 points for fresh and 45 days old cheese and obtained the highest total score points compared with other treatment. Total scoring points were $(68 / 81),(72 / 82)$ and $(78 / 88)$ point out of 100 for fresh and 45days old cheese for cow's, buffalo and mixed milk, respectively. These results are in harmony with El-Zoghby (1994), Mostafa et al. (1996) and Sameen et al. (2008).

\section{Conclusion}

Cheese producers always search for yield to make more profit while consumers search for acceptable hard cheese possibly to be sliced for the children sandwiches and accepted by different ages. So, preferable to manufacture Caerphilly like cheese from mixed milk $\mathrm{B}+\mathrm{C}$ $(1: 1)$ to satisfy both producers and consumers. 
Table 7. Effect of milk type on the organoleptic properties of Caerphilly cheese during storage at $5-7^{\circ} \mathrm{C}$

\begin{tabular}{|c|c|c|c|c|}
\hline \multirow[t]{2}{*}{ Type of milk } & \multirow{2}{*}{$\begin{array}{c}\text { Storage period } \\
\text { (day) }\end{array}$} & \multicolumn{3}{|c|}{ Treatment } \\
\hline & & Buffalo $100 \%$ & Cow $100 \%$ & Mixed B+C 1:1 \\
\hline \multirow{5}{*}{ Appearance (30) } & Fresh & 22 & 21 & 26 \\
\hline & 14 days & 23 & 22 & 25 \\
\hline & 30 days & 25 & 21 & 25 \\
\hline & 45 days & 24 & 21 & 27 \\
\hline & Fresh & 18 & 22 & 20 \\
\hline \multirow{3}{*}{ Body and Texture (30) } & 14 days & 21 & 23 & 22 \\
\hline & 30 days & 22 & 25 & 23 \\
\hline & 45 days & 24 & 26 & 24 \\
\hline \multirow{5}{*}{ Flavour (40) } & Fresh & 28 & 29 & 32 \\
\hline & 14 days & 29 & 31 & 33 \\
\hline & 30 days & 31 & 33 & 35 \\
\hline & 45 days & 33 & 35 & 37 \\
\hline & Fresh & 68 & 72 & 78 \\
\hline \multirow{3}{*}{ Total (100) } & 14 days & 73 & 76 & 80 \\
\hline & 30 days & 78 & 79 & 83 \\
\hline & 45 days & 81 & 82 & 88 \\
\hline
\end{tabular}

\section{REFERENCES}

Abo-El Naga, F.M. (1984). Direct Acidification in Hard Cheese Making. Ph.D. Thesis, Fac. Agric., Ain Shams Univ., Egypt.

AOAC (2000). American Official Analysis of Chemical Methods of Analysis, $17^{\text {th }}$ Ed., AOAC Int., Gaithersburg, MD, USA.

Awad, S.E., A. Ayed, A.H. and M. El-Soda (2003). Charactersation of Egyptian Ras cheese. 1. Sensory evaluation, rheological, phisyochemical, properties and microbiological analysis. Egypt. J. Dairy Sci., 31: 289-303.

Awad, S., A.N. Hassan and K. Muthukumarappan (2005). Application of exopolysaccharide producing cultures in reduced fat cheddar cheese: Texture and melting properties. J. Dairy Sci., 88: 4204 - 4213.
Bourne, M. (1978). Texture Profile Analysis. J. Food Techol., 32: 62-72.

Davide, C.L. (1994). New directions in low-fat dairy products processing towards better health. Philippine Agric., 77 (1): 1-16.

El-Metwally, M.M.M. (2013). Manufacture of Muenster cheese under the Egyption condition M. Sc., Fac. Agric., Mansoura Univ., Egypt.

El-Tahra, M.A.A., A.A. El-Shazly and M.S. Mostafa (2014). Effect of type of milk on the properties of Traditional Feta cheese. J. Food and Dairy Sci., Monsoura Univ., 5 (5): 315327.

El-Zoghby, A.S. (1994). Studies on Mozzarella cheese. Ph.D. Thesis, Fac. Agric., Zagazig Univ., Egypt. 
Helal, A.M.I. (2006). Manufacturing of Mozzarella caeriphilly cheese from cow's's and buffalo's milk with complete substitution of milk fat with vegetable oils. Ph.D. Thesis, Fac. Agric. (Damanhour), Alex. Univ., Egypt.

Kosikowski, F.V. (1970). Cheese and Fermented Milk Product $2^{\text {nd }}$ Ed., Edwards Brothers Inc., Am. Arbor, Michigan, USA.

Ling, E.R. (1963). A Text Book oOf Dairy Chemistry. Vol. 2. $3^{\text {rd }}$ Ed., Champonand Hall, London.

Metzger, L.E., D.M. Barbano, M.A. Rudan and P.S. Kindstedt (2000). Effect of milk preacidification on low fat Mozzarlla cheese. I. Composition and yield. J. Dairy Sci., 83: 648- 658 .

Michele, F., G.T. Kemerichi, B.L. Machadoiand and M.J. Maciel (2019). Effects of cow, goat, and buffalo milk on the characteristics of cream cheese with whey retention. Food Sci. Technol., Campinas, 39 (1): 122-128.

Mostafa, M.B.M., N.M. Shahein, Y.I. AbdelKader and A.S. El-Zoghby (1996). Properties of Caeriphilly Mozzarella cheese as affected by milk type. II-proteolysis, physical properties and organoleptic quality of cheese. Egypt. J. Dairy Sci., 24 (2):289-296.

Naema, F.G.A. (2017). Technological and microbiological studies on halloumi cheese M. Sc., Fac. Agric., Alex. Univ., Egypt.
Nelson, J.A. and G.M. Trout (1956). Judging Dairy Products $4^{\text {th }}$ Ed. The Olsen publishing Co. Milwaukee. Wis., 53212.

Sameen, A., F.M. Anjum, N. Huma, R. Kousar and H. Nawaz (2008). Impat of fat levels in milk on composition, sensory attributes and functionality of buffalo Caerphilly cheese. Pak. J. Agric. Sci., 45 (4): 463-467

Standard Methods for the Examination of Dairy Products (1978).

Stephan, W.G. and C.W. Stephan (2000). An integrated threat theory of prejudice. In $\mathrm{S}$. Oskamp (Ed.), the Claremont Symposium on Applied Social Psycholog. Reducing prejudice and discrimination. Lawrence Erlbaum Associates Publishers, 23-45.

Szczesniak, A., M. Brandt and H. Freidman (1963). Development of standard rating scales for mechanical parameters and correlation between the objective and sensory texture measurements. Food Technol., 22: 50-54.

Zaky, M.S. (2014) Studies on some factors affecting the Mozzarella caeriphilly cheese characteristics. Ph.D. Thesis, Fac. Agric., Alex. Univ., Egypt.

Zehren, V.L. and D.D. Nusbaum (1992). History of cheese making. Ch. 1 In Process Cheese, Cheese Reporter Publishing Co., Inc., Madison, WI. 


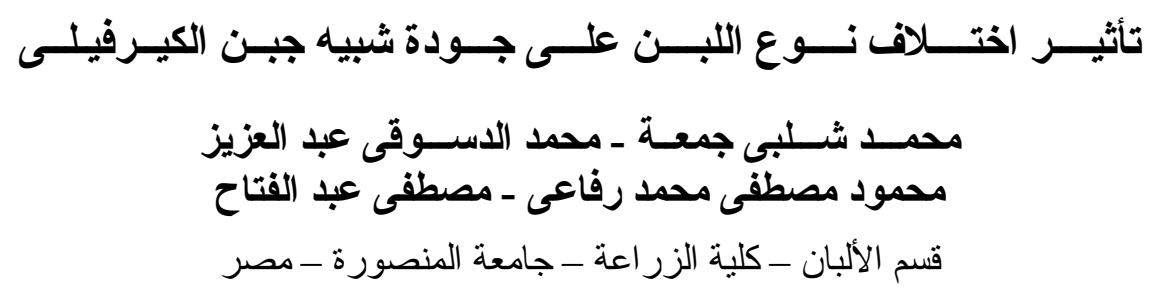

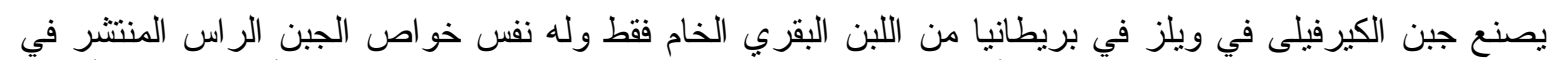

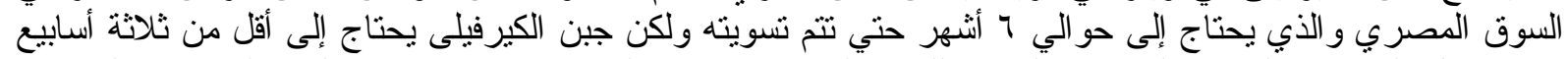

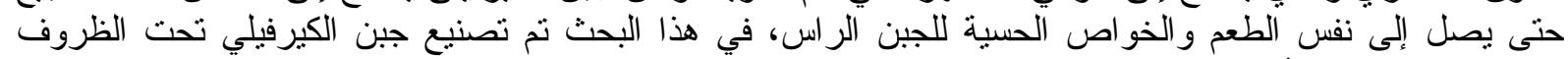

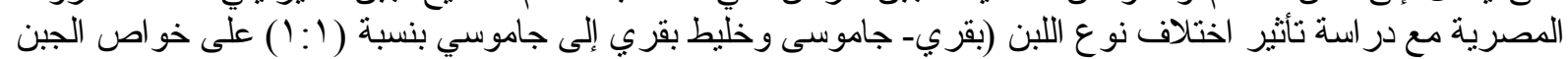

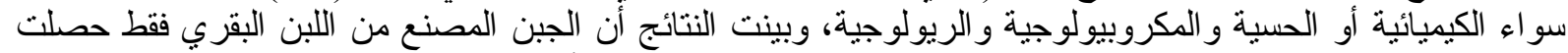

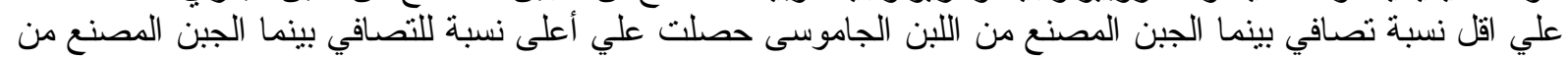

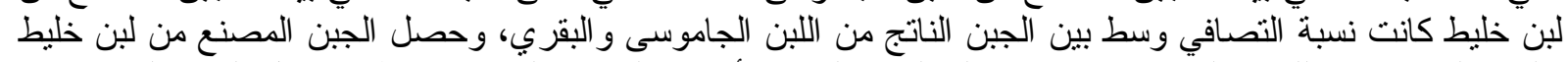

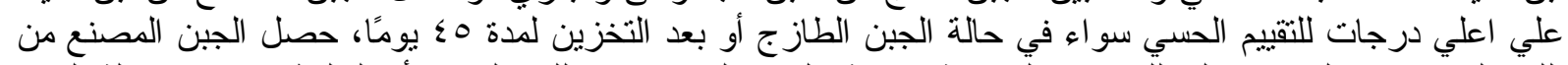

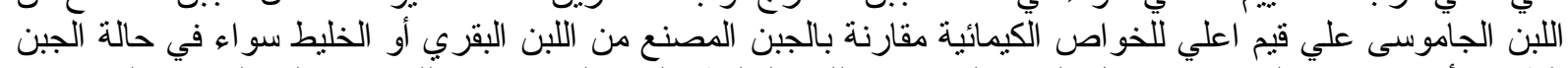

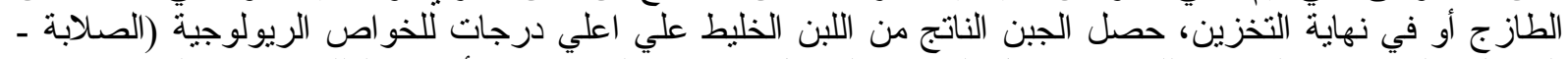


بصناعة جبن الكر فيلي من لبن خليط (بقري : جاموسي بنسبة ( : (). 